\title{
Башкирова О.А., Башкирова Е.А. \\ Формирование патриотизма студенческой молодёжи на примере героизма женщин в годы Великой Отечественной Войны
}

Омский государственный технический университет (Россия, Омск)

doi: 10.18411/lj-04-2021-132

\section{Аннотация}

В статье представлен фрагмент занятия о женщинах-участницах Великой Отечественной войны. Анализируется патриотическое воспитание в семье, школе и вузе. Рассматривается формирование патриотизма на примере героизма советских женщин в годы Великой Отечественной войны.

Ключевые слова: женщины-участницы Великой Отечественной войны; патриотическое воспитание; патриотизм; героизм

\section{Abstract}

The article presents a fragment of a lesson about women-participants of the Great Patriotic War. Patriotic education in the family, school and university is analyzed. The article considers the formation of patriotism on the example of the heroism of Soviet women during the Great Patriotic War.

Keywords: women-participants of the Great Patriotic War; patriotic education; patriotism; heroism

9 мая 2021 года исполняется 76 лет Победы нашей страны в Великой Отечественной войне. Всё дальше вглубь времён уходит Победа, но нельзя допустить, чтобы будущее поколение забыло о ней. Сохранить память о Великой Отечественной войне и о подвиге защитников Отечества, среди которых были наши отцы и матери, дедушки и бабушки, наш нравственный долг. Каждый человек должен знать свою историю, гордиться подвигами своих прадедов и брать с них пример, чтобы стать достойным гражданином и патриотом России. Первые уроки патриотического воспитания, связанного с Великой Отечественной войной, дети получают в семье. Рассматривая с родителями фотографии в семейном альбоме, слушая их рассказы о дедушках и бабушках, которые защищали нашу Родину в годы войны и совершали трудовые подвиги, в детях воспитывается чувство патриотизма.

Работа по патриотическому воспитанию продолжается и в детском саду, и в школе, и в вузе. Проводятся различные мероприятия, направленные на патриотическое воспитание, на уважение к старшим, на формирование правильных нравственных ценностей. «Цель патриотического воспитания - развитие в российском обществе высокой социальной активности, гражданской ответственности, духовности, становление граждан, обладающих позитивными ценностями и качествами, способных проявить их в созидательном процессе в интересах Отечества, укрепления государства, обеспечения его жизненно важных интересов и устойчивого развития» [1, С.10]. Воспитание на примерах героев Великой Отечественной войны является неотъемлемой частью формирования патриотизма у современной молодёжи.

Великая Отечественная война, начавшаяся внезапно 22 июня 1941 года, затронула судьбы многих людей. В период войны проявились лучшие качества советского народа, а победа в этой войне является одним из ярких образцов патриотизма, на котором должно воспитываться подрастающее поколение россиян. С началом Великой Отечественной войны на фронт ушли тысячи добровольцев, чтобы с оружием в руках защищать Родину. Среди добровольцев было немало женщин, которые проявили огромный героизм, громя фашистских захватчиков, не щадя жизни, демонстрируя чудеса храбрости и силы духа. Среди женщин были танкисты и 
разведчицы, лётчицы и снайперы, подпольщицы, но чаще всего медсёстры, врачи и санитарки.

Мы попросили студентов подготовить сообщения о советских женщинах участницах Великой Отечественной войны. Проводя занятие на эту тему, мы преследовали несколько целей:

1. Познакомить студентов с судьбами женщин, вставшими на защиту своей Родины и внёсшими неоценимый вклад в победу над фашизмом;

2. Сформировать чувство патриотизма на примерах героизма женщин в годы Великой Отечественной войны;

3. Воспитать чувство гордости за героизм советских женщин в борьбе с фашистскими захватчиками, за их любовь к народу и своей Родине.

Преподаватель: В годы Великой Отечественной войны в разных сражениях участвовали более 800 тысяч советских женщин, проявляя чудеса храбрости, силы духа и героизма. Каждый из вас подготовил сообщение о советских женщинах, участвовавших в Великой Отечественной войне и готов поделиться информацией со своими одногруппниками.

Глеб: Больше всего женщин на войне были медицинскими работниками. Медсёстры, постоянно рискуя своей жизнью, выносили раненых с поля боя, врачи проводили операции под обстрелами и бомбёжками. Раненые ласково называли их «сестричками». Мне хочется рассказать о Герое Советского Союза Зинаиде Александровне Самсоновой, которая ушла на фронт в 17 лет. Зинаида была санинструктором стрелкового батальона. Однополчане мило звали её Зиночкой. Бойцы любили её за улыбку, за самоотверженное оказание помощи раненым, за смелость и храбрость. Она воевала на разных фронтах, участвовала в самых страшных боях, вынося с поля боя десятки раненых. 27 января 1944 года Зинаида участвовала в бою за деревню Холм в Белоруссии. После гибели командира, она, не задумываясь, взяла на себя командование и подняла бойцов в атаку, крикнув: «Орлы, за мной!» В этом бою друзья - однополчане в последний раз услышали её удивительный, немного хрипловатый голос. За стойкость, мужество и отвагу Зинаиде Александровне Самсоновой посмертно присвоено звание Героя Советского Союза.

Никита: Я хотел бы добавить, что во многих городах нашей страны установлены монументы медсёстрам и врачам в память об их великом подвиге. Я видел скульптуру Е.В. Вучетича - девушка-санитарка несёт на плечах раненого солдата. Думаю, что эта скульптура посвящена всем девушкам-санитаркам, вынесшим с поля боя сотни раненых. Мы должны низко поклониться всем медицинским работникам за то, что они спасли тысячи жизней.

Преподаватель: Наверняка все вы слышали о женщинах-лётчицах, которых гитлеровские асы называли «ночными ведьмами». Возможно, многие видели фильм, снятый об этих лётчицах. Кто-нибудь подготовил сообщение о женщинах-лётчицах?

Лиза: Да, я видела фильм о «ночных ведьмах» и мне захотелось рассказать о женщинах-лётчицах, которые вели бои в воздухе, шли на таран, участвовали в ночных бомбардировках. Лётчиц 46-го Гвардейского Таманского полка боялись немецкие асы и прозвали их «ночными ведьмами». На бипланах У-2 они совершали налёты на немецкие эскадрильи. Руфина Сергеевна Гашева была штурманом эскадрильи, совершила 848 боевых вылетов. Гашева всегда находила выход из сложных ситуаций, в которые не раз попадала. Когда фашисты подбили её истребитель на Кубани, и он упал за линией фронта, Гашевой удалось пробраться в свой полк по вражескому тылу. В бою под Варшавой Гашевой пришлось на парашюте приземлиться на поле, заминированном противотанковыми минами, что спасло ей жизнь. Она благополучно перешла его и вышла к советским частям. В этом бою Гашева потеряла свою лучшую подругу Ольгу Санфирову. Руфина Гашева прошла всю войну, и в 1945 году ей было присвоено звание Героя Советского Союза с вручением ордена Ленина и Золотой Звезды. 
Мария: Лиза рассказала о женщинах-лётчицах, а я хочу рассказать о Петлюк Екатерине Алексеевне, которая тоже мечтала стать лётчицей, но при поступлении в школу пилотов имени Полины Осипенко медицинская комиссия отклонила её кандидатуру из-за маленького роста-151 см. Катя не отчаялась, окончила учёбу в Одесском аэроклубе и стала инструктором парашютного спорта. Знания, полученные в аэроклубе, помогли девушке в самом начале войны стать техником-укладчиком парашютов для лётчиков, которые отправлялись на боевые задания. В мае 1942 года Катя прибыла на комиссию по отбору добровольцев в школу танкистов. Хотя в танкисты брали только мужчин, комиссия не смогла устоять под напором и желанием девушки стать танкистом. Екатерине достался небольшой лёгкий танк Т-60, на башне которого она вывела надпись «Малютка». Во время боя «Малютка» был связным танком, который юрко проскакивал между разрывами, подкатывался к командирским машинам, получал приказы и мчался в подразделения. Кроме того, танк подвозил к подбитым машинам ремонтников и боеприпасы, отвозил в тыл раненых. В боях под Сталинградом на счету старшего сержанта Екатерины Петлюк было 10 уничтоженных блиндажей, 3 автомашины, 80 солдат и офицеров противника. За свои достижения девушка была награждена орденом Красной Звезды. После разгрома немецкофашистских войск под Сталинградом танк «Малютка» был отправлен в ремонт, и летом 1943 года Катя воевала уже на другой машине с таким же названием. Екатерина участвовала в боях на Курской дуге, показала себя опытным и решительным механиком-водителем и была представлена к ордену Отечественной войны II степени.

Преподаватель: С танком «Малютка» связана интересная история, которая имеет отношение к нашему городу Омску. Деньги на танк были собраны детьмидошкольниками Омска. Желая помочь Красной Армии, они, по примеру Ады Занегиной, отдали на строительство танка свои деньги, накопленные на игрушки и куклы. Дошкольники собрали 160886 рублей и просили назвать танк «Малютка». Екатерина узнала об этой истории уже после окончания войны.

Александра: Наша землячка Валентина Сергеевна Бархатова тоже была механиком-водителем танка. Первый бой девушка приняла на подступах к Сталинграду, вскоре на её боевом счету были десятки уничтоженных фашистов, несколько выведенных из строя орудий, дзотов и два танка. Несколько раз Валентина была ранена, но подлечившись, снова возвращалась на передовую и садилась за рычаги танка Т-34. В битве за Севастополь танк, в котором Валентина была в качестве радистки, подорвался на фугасе или неразорвавшейся авиабомбе. Бархатова была награждена медалью «За отвагу», орденом Красной Звезды и посмертно орденом Отечественной войны второй степени. В нашем городе есть улица, которой присвоено имя Валентины Сергеевны Бархатовой.

Преподаватель: В школе № 106 есть музей, в котором находятся фотографии Валентины Бархатовой, её письма с фронта и гипсовый бюст работы омского скульптора Анатолия Цымбала.

Алексей: Мне хотелось бы рассказать о женщинах-разведчицах, которые воевали в тылу врага, собирая сведения, необходимые нашему командованию. Советская разведчица Анна Морозова возглавляла подпольную интернациональную советско-польско-чехословацкую организацию. Благодаря собранным ею данным, были взорваны два немецких склада с боеприпасами, 20 самолётов и 6 железнодорожных эшелонов. В 1944 году девушка была ранена, и чтобы не попасть в плен, подорвала себя гранатой. Анна Морозова стала прототипом героини советского фильма «Вызываем огонь на себя» [2].

Преподаватель: Спасибо вам за рассказы о советских женщинах-участницах Великой Отечественной войны. Пока есть молодые люди, которые не равнодушны к 
теме войны, которым не безразлична история страны, будущие поколения будут знать и помнить о Великой Отечественной войне и её героях.

$* * *$

1. Концепция патриотического воспитания граждан Российской Федерации. - М., 2003.

2. Электронный ресурс URL: https://news.rambler.ru/incidents/36826216-ot-kosmodemyanskoy-do-koenznamenitye-sovetskie-razvedchitsy/(дата обращения: 15.03.2021).

\section{Бежанова Н...Л., Гаврилович Т.Г. \\ Критериальная характеристика проверки уровня сформированности знаний о картографических произведениях у учащихся третьего класса}

ФГАОУ «Севастопольский государственный университет»

(Россия, Севастополь)

doi: 10.18411/lj-04-2021-133

\section{Аннотация}

В статье представлены критерии и показатели, а также критериальная характеристика проверки уровня сформированности знаний о картографических произведениях у учащихся третьего класса.

Ключевые слова: знания, критерии, показатели, критериальная характеристика, проверка, уровень сформированности, учащиеся третьих классов, картографические произведения.

Abstract

The article presents the criteria and indicators, as well as the criteria characteristic of testing the level of cartographic works knowledge formation among third-grade students.

Keywords: knowledge, criteria, indicators, criteria characteristics, test, formation level, third-grade students, cartographic works.

На современном этапе развития образования в Российской Федерации одной из главных задач является формирование знаний о картографических произведениях. На это указывают такие официальные документы, как Федеральный государственный образовательный стандарт начального общего образования (ФГОС НОО) [2], Примерная основная образовательная программа начального общего образования (ПООП НОО) [3], на основании которых разработаны учебно-методические комплексы (УМК), в которых подтверждается необходимость формирования знаний о картографических произведениях у учащихся третьего класса. Федеральный закон "Об образовании в Российской Федерации, определяет цель начального общего образования в виде «формирования личности обучающегося, развития его индивидуальных способностей, положительной мотивации и умений в учебной деятельности» [1]. Следовательно, формирования знаний о картографических произведениях учащихся третьего класса приобретает особую актуальность, поскольку обществу необходима функционально грамотная личность, способная адаптироваться к жизненным условиям и требованиям, рационально влияя на неё. От того, насколько успешно будут сформированы знания учащихся третьего класса, зависит дальнейшее обучение в школе. Представленная возрастная категория нами выбрана не случайно, так как именно в третьем классе учащиеся приобретают первоначальные знания о том, что такое ориентирование, карта, глобус, получают начальные знания о Солнечной системе, Земле и её движении.

Процесс изучения картографических произведений обладает очень важными учебно-воспитательными функциями: выступает основой, на которую накладываются все географические знания; картографические произведения развивают географическое мышление, образное восприятие пространства, раскрывает 